\title{
A Review of School-Based Positive Psychology Interventions
}

\author{
Lea Waters \\ University of Melbourne, Australia
}

The aim of this paper is to review school-based interventions that have been designed to foster student wellbeing and academic performance by following a positive psychology approach that seeks to cultivate positive emotions, resilience and positive character strengths. Following the calls of the $21 \mathrm{st}$ century education movement for schools to incorporate student wellbeing as a focus of learning, the current paper outlines the positive psychology movement and reviews evidence from 12 school-based positive psychology interventions that have been systematically evaluated. The evidence shows that positive psychology programs are significantly related to student wellbeing, relationships and academic performance. The paper makes suggestions for the further development of positive psychology interventions in schools and explores the factors that could allow positive psychology to be extended, and more systematically embedded, into schools.

Keywords: Hope, gratitude, serenity, resilience, character strengths

\section{Youth Distress and the Need for a Focus on Wellbeing at Schools}

Today's students face a future of environmental degradation, peak oil, global warming, famine, poverty, health pandemics, population explosion, terrorism, increasing natural disasters, and other environmental and social issues. This complexity and stress is taking a toll on our young people's mental health. In Australia, 25\% of our young people (aged 15-19 years) have a mental disorder and one in three young people experience moderate to high levels of psychological distress (Australian Government Office for Youth, 2009).

Looking at the various ways in which this distress manifests itself, we find that $25 \%$ of young Australian people experience symptoms of depression (Australian Bureau of Statistics, 2008), 14\% experience symptoms of anxiety (Australian Institute of Health and Welfare, 2007), 32\% suffer body image issues (Mission Australia, 2007) and 13\% report substance abuse behaviours (Mission Australia, 2007), to name just a few issues. Tucci, Mitchell, and Goddard (2007) conducted an online study of 600 Australians (aged 10-14 years) and found that $46 \%$ of respondents did not feel confident or secure in themselves; $54 \%$ were worried about not fitting in; and $40 \%$ felt they were not performing well enough.

Address for correspondence: Professor Lea Waters, Melbourne Graduate School of Education, University of Melbourne, 717, 100 Leicester Street, Parkville VIC 3052, Australia. Email: l.waters@unimelb.edu.au 
In the face of rising levels of depression and distress (Wickramaratne, Weissman, Leaf, \& Holford, 1989), it is critical that we equip our young people with the skills to build resilience and hope in order to prevent mental illness. Importantly, we also need to equip our youth with the higher order cognitive, social and emotional skills that allow them to connect meaningfully with their communities.

Schools play an increasingly important role in assisting youth to develop cognitive, social and emotional skills. As such, calls have been made for schools to adopt a new paradigm of education for the 21st century. Twenty-first century schooling has been conceptualised in many different ways and has multiple components, including new technology, new pedagogies, interdisciplinary curricula, open learning spaces and reformed teacher training, to name a few (Fielding, 2001; Jackson \& Davis, 2000; MacDonald \& Hursh, 2006; Yates, 2007). However, a core proponent of all conceptualisations of 21st century schooling is the need for education to develop the 'whole student' through social, emotional, moral and intellectual development (Cain \& Carnellor, 2008; McCombs, 2004; Noddings, 1995; Palmer, 2003). The focus of this review paper is the use of positive psychology interventions to assist such wholestudent learning.

Yates (2007, p. 35) argues that 'While older educational agendas such as literacy and numeracy remain significant ... education is increasingly important for its role in assisting young people to develop the capacities and skills that will enable them to live well and that will enhance social cohesion'. The National Scientific Council on the Developing Child (2006, p. 7) states that 'If we really want to build a strong platform for healthy development and effective learning ... then we must pay as much attention to children's emotional wellbeing and social capacities as we do to their cognitive abilities and academic skills. There is no doubt that teaching for wellbeing is a key aspect of 21 st century education. Wellbeing in this paper is defined as 'the combination of feeling good and functioning well' (Huppert \& Johnson 2010, p. 264).

\section{Positive Psychology and Positive Education}

Positive psychology is a relatively new branch of psychology that conducts scientific inquiry into the factors that help individuals, communities and organisations thrive by building on their strengths and virtues (Gable \& Haidt, 2005). Positive psychology aims to expand the field from its focus on repairing the negatives in life to also promoting the positives in life (Seligman \& Csikszentmihalyi, 2000). According to Norrish and Vella-Brodrick (2009, p. 275), 'Positive psychology aims to contribute to a comprehensive approach to mental health by adding an investigation of positive emotions and human strengths to existing knowledge on mental illness and dysfunction'. Pawelski (in press, p. 9) adds to Norrish and Vella-Brodrick's (2009) argument by stating that 'studying the positive can give us new knowledge about human flourishing, knowledge that would not be available to us if we simply studied the negative, no matter how comprehensively we did so'. Wong (2011, p. 77) emphasises that a key goal of positive psychology is to 'develop good and decent people as well as a civil society by promoting meaning/virtue'. The emphasis of positive psychology on wellbeing, flourishing, character, meaning and virtue aligns strongly with the ethos of whole-student learning in 21st century schooling.

Positive psychology interventions (PPIs) are characterised by Sin and Lyubomirsky (2009, p. 467) as programs, practices, treatment methods or activities 'aimed at 
cultivating positive feelings, positive behaviours, or positive cognitions'. Seligman's model of positive emotions, engagement, relationships, meaning and accomplishment (PERMA model) suggests that these are the five enabling factors that should be built into PPI's. In this way, positive psychology interventions distinguish themselves from wellbeing initiatives such as antibullying programs, 'quit smoking' programs, and depression-reduction programs that seek to enhance wellbeing through the removal or reduction of negative factors.

Whilst the removal of negative factors is a critical pathway to creating wellbeing, the two-factor theory of wellbeing (Keyes, 2002) highlights that we also need programs that are designed to build the positive factors. As stated above, research and practice in positive psychology seeks to add to, rather than replace, the approaches to wellbeing that seek to reduce negative factors.

Green, Odes and Robinson (2011, p. 16) define positive education as applied positive psychology in education', and they suggest that there are a growing number of schools using PPIs. Seligman, Ernst, Gillham, Reivich, and Linkins (2009) define positive education as an approach to education that fosters traditional academic skills and skills for happiness and wellbeing. Researchers and practitioners in the positive education movement argue that schools can 'teach both the skills of wellbeing and the skills of achievement' (Seligman, et al., 2009, p. 294) without compromising either (Department of Education and Training, 2002). Positive education also works on the precept that the skills and mindsets that promote positive emotions, positive relationships and character strengths also promote learning and academic success (Bernard \& Walton, 2011).

Indeed, research evidence is now mounting to show that student wellbeing is positively related to academic performance. For example, a meta-analysis by Durlak, Weissberg, Dymnicki, Taylor, and Schellinger (2011) of 213 studies involving 270,034 students from kindergarten through high school showed that, on average, school students enrolled in a social and emotional learning program ranked 11 percentage points higher on achievement tests than school students who did not participate in such programs.

A key tenet within the field of positive education is that the skills and mindsets that promote positive emotions, positive relationships, resilience and character strengths can be explicitly taught and assessed by schools (Green et. al, 2011; Norrish \& VellaBrodrick, 2009; Seligman et. al, 2009). Just as there are formulas and practices used to teach the skills of literacy and numeracy, there are formulas and practices that can be used to teach the skills for wellbeing.

However, before educators are likely to take on positive psychology approaches in schools, they need to be informed by evidence that PPIs are effective at building wellbeing in students. As such, the aim of this paper is to review school-based interventions that have been designed to foster student wellbeing and academic performance by following a positive psychology approach that focuses on cultivating positive emotions (e.g., hope, gratitude and serenity), resilience and character strengths.

\section{A Review of School-Based Positive Psychology Interventions}

The following section will review evidence from 12 school-based PPIs. These interventions have been variously designed to teach students how to cultivate their own positive emotions (e.g., hope, gratitude and serenity), resilience and character 
strengths. In order to qualify for review in this paper, the PPI had to meet three key criteria. First, following Sin and Lyubomirsky's (2009) definition, the PPI had to have an approach that aimed to build positive factors, rather than solely focusing on the reduction of negative factors. Second, the PPI had to be implemented with students at school, rather than youth wellbeing programs run in other settings (e.g., church settings, community settings, clinical settings). Third, the PPI had to be evaluated using valid and reliable research designs and measures. In conducting this review, the aim was to report on evaluations that have been conducted across junior, middle and senior schools, that have been implemented across different school systems (e.g., public schools and private schools), that come from different countries and that have been used with students of both genders and various races.

\section{SCHOOL-BASED POSITIVE PSYCHOLOGY INTERVENTIONS THAT CULTIVATE HOPE IN STUDENTS}

Synder (1995, p. 355) defined hope as 'the process of thinking about one's goals, along with the motivation to move toward those goals (agency) and the ways to achieve those goals (pathways)'. In hope theory, goals are the targets of mental action sequences, and they anchor purposive behaviour. Marques, Pais-Ribeiro, and Lopez (2009) found that a child's hopeful thinking is positively associated with perceived competence, self-esteem, life satisfaction and mental health. Valle, Huebner, and Suldo (2006) investigated the relationship between hope and life satisfaction in school students aged 10-18 years over a 1-year period. When controlling for initial life satisfaction, those students with high hope at the first time point reported higher life satisfaction a year later.

Green, Anthony, and Rynsaardt (2007) conducted a randomised controlled experimental trial with 56 Australian female senior students from a private girls' high school (mean age 16 years). Students were randomly allocated to a coaching intervention $(n=28)$ or a wait-list control group $(n=28)$. The coaching group met with their teacher-coach 10 times over two school terms. Pretest measures were taken of both groups on hope, cognitive hardiness, depression, anxiety and stress. The results showed a significant treatment by time interaction effect for hope and hardiness, in that these two constructs improved over time for students in the coaching group but not for those in the control group. In addition, depression and anxiety dropped significantly over time for students in the coaching group but not for those in the control group. There were no significant differences in stress. The authors concluded that hope can be promoted at school through goal setting and coaching interventions.

Marques, Lopez and Pais-Ribeiro (2011) investigated the effectiveness of a 5-week, hope-based intervention run by the researchers with middle-school students (age range $=10-12$ years) in Portugal. The program was designed to enhance hope, life satisfaction, self-worth, mental health and academic achievement. Thirty-one students formed the hope intervention group and received a total of $5 \times 60$-min sessions once a week. Another 31 students formed the control group, which was matched with the intervention group according to age, gender, school year, ethnicity, hope, mental health, life satisfaction, self-worth and academic achievement. Students in both groups completed assessments at pretest and immediate posttest, and at 6-month and 18-month follow-up. The post-test results showed that the intervention group had significantly enhanced levels of hope, life satisfaction and self-worth and these benefits 
were maintained at the 18-month follow-up. There was no significant difference in academic achievement between the hope group and the control group over time. The authors concluded that a brief hope intervention delivered at school can increase wellbeing and that these benefits are long lasting.

\section{SCHOOL-BASED POSITIVE PSYCHOLOGY INTERVENTIONS THAT CULTIVATE GRATITUDE IN STUDENTS}

Gratitude is defined as 'a sense of thankfulness and joy in response to receiving a gift, whether the gift be a tangible benefit from a specific other or a moment of peaceful bliss evoked by natural beauty' (Peterson \& Seligman, 2004, p. 554). In youth samples, gratitude has been significantly associated with positive affect, life satisfaction, optimism, social support and prosocial behaviour (Froh, Yurkewicz, \& Kashdan, 2009). Froh and colleagues have recently turned their attention towards PPIs that can be implemented at schools to enhance gratitude in students.

Froh, Sefick, and Emmons (2008) designed a 'counting blessings' intervention for sixth and seventh graders $(N=221)$ and randomly assigned 11 classrooms to one of three conditions. Four classes were allocated to the gratitude condition, four classes were allocated to the hassles condition, and three classes served as no-treatment controls. Students in the gratitude and hassles classrooms were asked by their teachers to fill in a daily journal for 2 weeks. Students in the gratitude condition were instructed to record up to five things they were grateful for. Students in the hassles condition were asked to write about things that irritated or annoyed them. Measures of psychological, physical and social wellbeing were taken at pretest, immediate posttest and a 3-week follow-up. The students in the blessings condition reported more improvements in gratitude, optimism and life satisfaction than their fellow students in the hassles and control groups. The relation between feeling grateful for help from others and positive affect became stronger during the 2-week intervention and was strongest 3 weeks after the intervention ended. Students instructed to count blessings, compared with those in the hassles or control conditions, reported more satisfaction with their school experiences.

In a second school-based gratitude intervention, Froh, Kashdan, Ozimkowski, and Miller (2009) worked with teachers to implement a 'gratitude visit' with students in grades 3, 8 and 12 (age range $=8-19$ years) in a parochial school. Students were randomly assigned to either the gratitude intervention or a control condition. Students in the gratitude classes were asked to write and deliver a letter of gratitude to someone important to them. Students in the control classes were asked to write a journal about some of the things they had done the day before, and how they felt when they were doing those things. Both conditions were implemented during class time over a 2-week period. There was no significant interaction between condition and time for gratitude. However, when the researchers looked more closely at those students who were low in positive affect at the start of the intervention, those who were in the gratitude classes reported more gratitude immediately following the intervention, compared to those in the control classes. Moreover, those students low in positive affect who were in the gratitude classes reported more positive affect 3 months later. Given the finding that gratitude may strengthen supportive relationships (Froh, Yurkewicz, \& Kashdan, 2009), it seems that those students low in positive affect could benefit further from gratitude interventions, not only from the increase in gratitude and positive affect, but also through its concomitant effect on receiving social support. 


\section{SCHOOL-BASED POSITIVE PSYCHOLOGY INTERVENTIONS THAT CULTIVATE SERENITY IN STUDENTS}

Frederickson (2009) lists serenity as one of the top 10 most important positive emotions and characterises it as feelings of peacefulness, stillness and calm. Research into the benefits of feeling serene has shown that this emotion allows for insight generation, expanded attention, integration of thoughts and emotions, stress reduction and heightened compassion (Keegan, 2009; Levine, 2009; Thygeson, Hooke, Clapsaddle, Robbins, \& Moquist, 2010). Research evidence suggests that many students do not feel calm or peaceful when they are at school (Grannis, 1992; Burchinal, Roberts, Zeisel, \& Rowley, 2008; Byrne, Davenport, \& Mazanov, 2007).

One accepted technique shown to promote the positive emotion of serenity is meditation, which is defined as 'a process of paying attention, often to a particular object designated as the focus of concentration' (Campion and Rocco, p. 47). In adult samples, the practice of meditation has been shown to promote serenity, as well as increase compassion, reduce anxiety, improve physical health, facilitate self-kindness, heighten self-knowledge and promote self-regulated behaviour (Davidson et.al., 2003; Grossman, Niemann, Schmidt \& Walach, 2004; Kabat Zin, 1994). Researchers and educators have called for the use of meditation as a school-based practice to assist the wellbeing of students (Campion \& Rocco, 2009; Huppert \& Johnson, 2010). Although the evidence in this area is new, it is promising, and research has demonstrated the potential of meditative practices to support the goals of education such as improved attention, concentration, creativity and self-regulation (Cowger \& Torrance, 1982; Goleman, 1995; Mayer \& Salovey, 1997).

Mindfulness is a state of intentionally and nonjudgementally paying attention to the present moment (Kabat-Zinn, 1994). Mindfulness meditation is a form of meditation in which distracting thoughts and feelings are not ignored but, instead, acknowledged and observed nonjudgmentally as they arise, in order to detach from them and gain insight and awareness. Broderick and Metz (2009) evaluated a sixlesson mindfulness meditation curriculum delivered at an all-girl Catholic school in Pennsylvania. One hundred-and-twenty seniors (average age 17.4 years) participated as part of their health curriculum, and 30 junior students from the same high school served as the control group. A pretest-posttest design was used. The results at posttest (1 week after the mindfulness curriculum was completed) showed that, relative to control students, the intervention students reported increased feelings of calmness, relaxation and self-acceptance, as well as decreased negative affect. Emotion regulation improved and somatic complaints decreased in the intervention classes at the conclusion of the program.

Huppert and Johnson (2010) examined the effect of mindfulness training with 173 students (age range $=14-15$ years) from two private ${ }^{1}$ English boys' schools. The mindfulness training was undertaken by students as part of their religious instruction curriculum. Six of the religious instruction classes used mindfulness training and five classes acted as controls. The students in the mindfulness-training group had four mindfulness lessons over a 4 -week period. The students in the mindfulness training group were compared to those in the control group on measures of mindfulness, resilience and psychological wellbeing. At the end of the 4-week program, there was no difference in wellbeing and resilience between the two groups. However, within the mindfulness group, there was a significant relationship between the frequency of mindfulness practice and wellbeing. The students reported that they enjoyed the 
mindfulness training and $74 \%$ indicated that they would like to continue the mindfulness practice.

Another meditation technique is that of Transcendental Meditation. Transcendental Meditation is a technique for attaining a state of physical relaxation and psychological calm by the regular practice of a relaxation procedure that entails the repetition of a mantra to block distracting thoughts. Nidich et al. (2011) evaluated the use of the Transcendental Meditation program on student wellbeing, social behaviour and academic performance for middle-school students in a public school in California. Students $(n=125)$ were placed into the experimental group and engaged in a 12-min meditation session at the start and the end of the school day for 3 months. The control group participated in the school's quiet-time program, 12 min of quiet time each day, but did not meditate. Teachers reported that the students in the meditation group were calmer, happier, less hyperactive, friendlier and had an increased ability to focus on schoolwork, compared to preprogram. The results showed that students who practiced the Transcendental Meditation program had significant increases in Math and Englishscale scores, and performance-level scores, over a 1-year period. Forty-one percent of the meditating students showed a gain of at least one performance level in Math, compared to $15.0 \%$ of the nonmeditating controls.

\section{SCHOOL-BASED POSITIVE PSYCHOLOGY INTERVENTIONS THAT FOCUS ON DEVELOPING RESILIENCE IN STUDENTS}

Resiliency is positively linked with the ability to recover from setbacks and stress, as well as the ability to reach out and seek new opportunities for growth (Reivich \& Shatte, 2002). So what happens if schools deliberately design PPIs that build resiliency in students? This section outlines the results of 20 studies that have focused on two curriculum-based resiliency programs taught in schools. The programs have been shown to reduce distress, improve wellbeing and promote learning.

The Penn Resiliency Programme (PRP) is a curriculum-based program that is designed to boost student resilience and has been implemented in schools in the United States of America, United Kingdom, Australia, China and Portugal. The program teaches cognitive reframing, assertiveness, decision making, coping skills, creative brainstorming and relaxation, and has been used with students from ages 8 to 15 years. In a review of the findings from 17 studies comparing over 2,000 students who went through the program to students in control groups, Seligman et al. (2009) reported that the PRP resiliency training reduced symptoms of depression, hopelessness and anxiety. Encouragingly, the positive benefits of the PRP appeared to be long lasting, with significant improvements in wellbeing found at 2-year and 31month retests. In addition to mitigating distress, the PRP has been shown to significantly increase optimism (Brunwasser \& Gillham, 2008).

In Australia, Bernard and Walton (2011) evaluated the efficacy of a social and emotional resiliency skills curriculum called 'You Can Do It!' (YCDI). The YCDI program gives lessons in resilience, confidence, persistence, organisation and getting along. The researchers compared students in Grade 5 from six government schools that had implemented the YCDI program ( $n=349$ students) against students in Grade 5 from six government schools that had not implemented the program (control $n=208$ ). The students were compared on their responses to the Student Attitudes to School Survey (SASS; Department of Education and Early Childhood Development, 2006), which assesses student self-reports on wellbeing, teaching and learning. 
Students were tested in Grade 5 and then again 1 year later in Grade 6. Over the 1-year period, the self-report data provided by students in the YCDI schools showed significant improvements in student morale, stimulating learning, school connectedness, student motivation, learning confidence, connectedness to peers, classroom behaviour and student safety. In addition, student distress was reduced. By contrast, the students in the non-YCDI schools reported improvements in only two areas, classroom behaviour and student safety.

\section{SCHOOL-BASED POSITIVE PSYCHOLOGY INTERVENTIONS THAT FOCUS ON DEVELOPING CHARACTER STRENGTHS IN STUDENTS}

Character strengths are defined by Brdar and Kashdan (2010, p. 151) as 'pre-existing qualities that arise naturally, feel authentic, are intrinsically motivating to use and energising'. Character strengths such as love, hope, curiosity and zest have high correlations with life satisfaction, pleasure and engagement in adults (Park, Peterson, \& Seligman, 2004; Peterson, Ruch, Beermann, Park, \& Seligman, 2007). Hope, kindness, social intelligence, self-control and perspective have also been shown to buffer people from the negative effects of stress and trauma (Park \& Peterson, 2009a). In middle-school students, Park and Peterson (2008) found that the character strengths of persistence, honesty, prudence and love were negatively correlated with aggression, anxiety and depression. The character strengths of perseverance, fairness, gratitude, honesty, hope, and perspective were significant predictors of grade-point average above and beyond IQ (Park and Peterson, as cited in Park \& Peterson, 2009b). Duck and Seligman (2005) looked at the specific character strength of self-discipline and its relationship to academic performance in eighth-graders. The results of their longitudinal study showed that self-discipline out-predicted IQ on academic performance. Yost (1967) conducted a longitudinal assessment of the character strength of curiosity in fourth-grade students and found that it predicted academic success when those students were retested in sixth grade. Hence, the use of PPIs designed to foster character strengths at school holds great promise. The current paper reviews three such PPIs below.

The Strathhaven Positive Psychology Program was developed in the United States of America and is designed to teach school children the skills required for creating positive emotions and to allow students to identify and use their own character strengths. The program consists of 20-25 lessons and uses Peterson and Seligman's (2004) Values in Action (VIA) framework, which consists of 24 character strengths that fall under one of six core virtues: wisdom, courage, humanity, justice, temperance and transcendence.

Seligman et al. (2009) conducted an evaluation of the Strathhaven Positive Psychology Program with 347 Year 9 students who were randomly allocated to language arts classes that contained the positive psychology curriculum (positive psychology condition) or did not contain the positive psychology curriculum (control). The researchers collected pretest and posttest data, including 2-year followup data, from the students in both groups and their teachers and parents. Data were collected on students' character strengths, social skills, behavioural problems, and enjoyment of school and grades. Notably, the teachers who were asked to assess students on character strengths, social skills and behavioural problems were not those teachers who delivered the positive psychology curriculum and, as such, did not know which students participated in the program and which students did not. 
Pretest to posttest comparisons revealed that the students in the positive psychology program reported greater enjoyment and engagement in school at the end of the program. Teacher reports showed that the program improved the strengths in students that related to learning and engagement in school, such as curiosity, love of learning and creativity. Teachers and parents also reported improvement in social skills for those students who participated in the positive psychology curriculum. However, students in the PPI did not show any changes in their depression and anxiety.

In Australia, Madden, Green, and Grant (2010) designed and evaluated a strengthsbased coaching program for primary school children based upon the VIA character strengths framework and using the youth VIA survey. The researchers designed a program that was intended to assist students in Grade $5(N=38$; mean age $=$ 10.7 years) at a private all-boy school to identify their character strengths, set goals to use these strengths in innovative ways and write a 'letter from the future' to themselves that involved writing about themselves at their best. The strengths-based coaching program formed part of the curriculum in the personal development/health streams. The students received eight coaching sessions from a teacher within the school over two school terms. A within-subject design was used to evaluate the program, whereby students were pretested on levels of hope and levels of engagement and were given the same survey at the end of the strengths-based coaching program. At posttest, students reported increases in hope and engagement, suggesting that the character strengths curriculum was beneficial for students.

Using the Gallop Strengths Framework, Austin (2005) compared educational outcomes of students who were randomly assigned to a 6-week strengths program ( $n$ $=255)$ with students in a standard curriculum control condition $(n=272)$. Students in the strengths condition completed the Gallup Clifton Strengths Finder to discern their top five strengths, shared their strengths with friends and family, and completed strengths diaries. The results showed that, after completion of the strengths program at school, students in the strengths group had significantly higher academic expectations, efficacy, self-empowerment, extrinsic motivation and perceptions of ability, as compared to the control students.

The results from the three evaluations above show that character strengths can be explicitly taught in schools and that, when character strengths are included in the curriculum, students are able to further develop their character strengths and social skills, as well as benefit from greater enjoyment, hope, engagement and academic confidence.

\section{SYNTHESIS OF SCHOOL-BASED POSITIVE PSYCHOLOGY INTERVENTION REVIEW}

The PPIs reviewed in this paper have been drawn from international studies, have covered five specific PPI foci (i.e., gratitude, hope, serenity, resilience and character strengths), have been implemented across different school systems (e.g., public schools and private schools), have been used in coeducational settings and singlegender schools, have been used in age ranges from 5 to 19 years, and have been implemented with students of various ethnicity. Taken together, the results are significant, robust and promising.

A strength of the PPIs reviewed above is the large sample sizes of a number of the studies, such as the sample size of 347 students used in the Seligman et al., (2009) study, the sample size of 221 students used in the Froh et al., (2008) study and the sample size of 173 students used in the study by Huppert and Johnson (2010). The use 
of control groups with which to compare the efficacy of the PPIs is also a strength of the PPI research conducted to date. Some studies were able to randomly allocate students into condition versus control groups, which lends greater validity to the study results. However, most of the studies were unable to use random assignment due to specific year levels being used or particular student groups being targeted for the intervention. Some studies used small sample sizes due to the intensive nature of the program or the small size of the class in which the PPI was administered (e.g., Madden et al., 2010; Marques et al., 2011). Many of these studies were evaluated in their pilot stage, hence, further evaluation of these programs is required as they are developed beyond pilot programs and are used with multiple student groups, larger sample sizes and across multiple settings. In addition, the validity of the PPIs could be examined by evaluating the responses of parents and teachers about the students, as was done by Seligman et al. (2009), rather the relying solely on the self-report of the students.

There are a number of features of the PPIs reviewed above that can be suggested to researchers, teachers and practitioners who are seeking to develop positive psychology wellbeing programs. The review of the 12 PPIs found that a common factor of the programs was that most of the PPIs were implemented by the teachers. This may have enhanced the success of the programs, given that teachers already have an ongoing relationship with the students and can also keep reinforcing the lessons after the curriculum has been completed. Another design feature that shows promise is the infusion of teaching positive psychology skills (e.g., character strengths and meditation) into the already established school subjects such as arts language, health development and religion. However, the programs that were housed in pastoral care (e.g., Green et al., 2007; Nidich et al., 2011) also proved to have a significant effect on student wellbeing.

\section{Cultivating Positive Education in Schools}

Although positive education is a relatively new field, the research, as outlined above, has already built up a convincing case for the success of such an approach in schools. Perhaps this is, in part, due to the natural alignment of positive education with the calls for 21st century schooling to develop the whole student. Clonan, Chafoulea, McDougal, and Riley-Tillman (2004, p. 101) argue that schools 'serve as the nexus between the movement in positive psychology searching to promote positive human development and the institutions that could serve as the vehicle for this development'. This section discusses four factors that may assist schools to cultivate positive education: (a) extending positive psychology topics into traditional academic disciplines, (b) using a school-wide approach, (c) using strategic frameworks to guide the rollout of positive psychology in schools, and (d) the supporting role of larger educational systems.

\section{EXTENDING POSITIVE PSYCHOLOGY TOPICS INTO TRADITIONAL ACADEMIC DISCIPLINES}

Positive education argues that wellbeing is of equal priority to academic learning in developing the whole student. As such, the school-based positive psychology interventions reviewed above had designed a 'wellbeing curriculum'2 that explicitly taught students the skills to enhance their positive emotions and character strengths in order to promote wellbeing. However, in addition to the use of specific interventions 
that teach wellbeing skills (e.g., keeping a gratitude journal), students can also be exposed to positive psychology through the inclusion of positive psychology topics into the curriculum of traditional academic disciplines. Pawelski (in press, p. 6) calls for academic curriculum to take a 'positive turn' in the topics studied within the academic curriculum so that the teachers present topics and subject matter that seek to understand human flourishing. For example, English curriculum could study hope and gratitude as topics in their analysis of character and text. Moreover, in English literature, students can learn the skills of analysis, argument formation, and writing by studying uplifting text such as Invictus by William Ernest Henley, in addition to the darker syllabus such as Inferno by Dante. Cultural and religious curriculum could explore mindfulness and meditation, performing arts could study self-expression through joy, empathy and creativity, geography could analyse the differences in happiness across continents. By adopting a 'positive turn' in curriculum, schools can seek to reinforce the explicit wellbeing skills that are taught in PPIs with a more academic analysis and understanding of the factors that contribute to flourishing.

\section{USING A SCHOOL-WIDE APPROACH}

To date, the evolution of positive psychology in schools has been at the level of specific PPIs that have been implemented in isolated classrooms or through pastoral care initiatives. However, for the positive outcomes above to be wide reaching and sustained, students need to be exposed to positive psychology across multiple year levels of their schooling and within various sections of their schools. As well as the explicit PPIs, positive psychology needs to be woven into the 'DNA' of the wider school culture. A systems approach is required to embed positive education through cocurriculum, pastoral care programs and behavioural management policies.

Whole-of-school approaches are required, in which all staff (teaching and nonteaching) are trained in positive education techniques so that the principles of positive psychology are modelled and supported throughout the entire fabric of the school. When teachers and school staff have high levels of social and emotional wellbeing, this has a positive influence on the students (Jennings \& Greenberg, 2009). The PPIs reviewed above found that the programs were successfully delivered by teachers and did not require an external expert to deliver the curriculum. This finding lends support to the suggestion for positive education training to be delivered to teachers. The positive psychology training would also be helpful if future evaluations of PPIs included teacher reports in addition to student reports, because the teachers who are trained will have an understanding of the positive psychology evaluation indices used.

In addition to staff training, positive psychology needs to be built into school human resource policies and practices such as staff recruitment and selection, performance development, performance appraisal, promotion, parent-teacher communication, teaching teams and remuneration.

\section{USING STRATEGIC FRAMEWORKS TO GUIDE THE ROLL-OUT OF POSITIVE PSYCHOLOGY IN SCHOOLS}

A school-wide positive education framework (PEF) is required to ensure that schools move beyond the use of specific programs conducted within selected classrooms to adopting a whole-school approach that becomes the general way of life at the school. As indicated above, positive education frameworks need to target curriculum, 
cocurriculum, pastoral care, the broader teaching and learning environment, and the playground, as well as organisational structures, policies and processes, so that every aspect of school culture is supporting the conditions that allow students and staff to thrive. Principals need to ensure that all key stakeholders are engaged and supported in the school's positive education transformation. These key stakeholders are leaders (including school leadership teams, school boards and councils), staff, students, parents, communities and educational governing systems. Creating 'buy in' across the key stakeholders allows a common language and ideology to be developed.

Seligman's (2011) PERMA model would be a useful framework for assisting school leaders to foster positive education in their institutions. The PERMA model argues that there are five enabling conditions for wellbeing, which are positive emotions, engagement, relationships, meaning and accomplishment. This model establishes a framework that embraces the promotion of one's own wellbeing and achievement whilst simultaneously fostering a concern for others and the capacity to participate in civic responsibilities. The use of the PERMA framework gives school leaders a way of ensuring that students across all levels and areas of the school are provided with an environment that meets the five elements. Principals can conduct a positive psychology audit of their schools to see whether school policies and programs, as well as staff and student practices, are providing all five elements of the PERMA model. A positive psychology audit provides evidence to school leaders as to the areas of the school that need redesigning. Following the audit, the five pillars of PERMA can be built into the school's strategic plan so that the required expenditure, training and resources are systematically built up over time to create a positive education environment.

Alternatively, Noble and McGrath's (2008, p. 119) positive education practices (PEP) framework could be used as 'an organising tool for facilitating ... pupil wellbeing and supporting pupils to achieve learning outcomes and engage in prosocial behaviour'. Like PERMA, the PEP framework also has five key foundations of wellbeing, which are social and emotional competency, positive emotions, positive relationships, engagement, and a sense of meaning and purpose.

\section{THE SUPPORTING ROLE OF LARGER EDUCATIONAL SYSTEMS}

Schools, school systems and universities need to be thinking strategically about how to embed positive psychology into the culture of teacher training, school leadership training and system-wide educational initiatives in order to create a positive and productive environment for students. Education systems need to support the change towards 21 st century schools and the positive education movement by expanding the metrics upon which they evaluate school performance. Judgments about school success typically focus on academic performance (Murray-Harvey \& Slee, 2007). Wellbeing should also be an accepted indicator of school success (Huebner, Gilman, Reschly, \& Hall, 2009; Judge \& Kammeyer-Mueller, 2011). Indeed, Huebner (2010, p. 1) argues that a key indicator of schools is 'one in which a preponderance of students experienced predominantly positive emotions and a strong sense of overall wellbeing.

\section{Conclusions}

This paper reviewed 12 school-based interventions that have been designed to foster student wellbeing and academic performance by following a positive psychology approach. The evidence is promising and shows that positive psychology interventions 
are significantly related to student wellbeing and academic performance. The results can be used to encourage researchers, teachers and practitioners to assist students with wellbeing by showing students how to foster the positive elements of their lives such as positive emotions, resilient mindsets and positive character. The evidence of this paper can be used to assist schools in adopting a positive psychology approach.

The Curriculum Standing Committee of the National Education Professional Association's report on developing a 21st century curriculum for all Australian students posits that the remit of schools is to develop successful learners who are confident individuals and responsible citizens. Positive education offers a scientifically validated approach to ensure such outcomes are achieved.

\section{Endnotes}

1 Private $=$ fee-paying

2 Three of the studies reviewed in this paper inserted the positive psychology skills training into existing academic curriculum such as arts language, health and religion. Room was made in the curriculum of the academic subject to learn the skills for promoting positive emotions and character strengths.

\section{References}

Austin, D. (2005). The effects of a strengths development intervention program upon the self-perception of students' academic abilities. Dissertation Abstracts International, 66, 1631A.

Australian Bureau of Statistics. (2008). 2007 National survey of mental health and wellbeing: Summary of results (4326.0). Canberra: Author. Retrieved from http://www.abs.gov.au/ausstats/ abs@.nsf $/ \mathrm{mf} / 4326.0$

Australian Government Office for Youth. (2009). State of Australia's young people. Social Policy Research Centre, Department of Education, Employment and Workplace Relations. Retrieved from http://www.deewr.gov.au/Youth/OfficeForYouth/Documents/StateofYoungPeople.pdf

Australian Institute of Health and Welfare. (2007). Young Australians: Their health and wellbeing 2007. Cat. no. PHE 87. Canberra: Author. Retrieved from http://www.aihw.gov.au/WorkArea/ DownloadAsset.aspx?id=6442459814

Bernard, M., \& Walton, K. (2011). The effect of You Can Do It! Education in six schools on student perceptions of wellbeing, teaching, learning and relationships. Journal of Student Wellbeing, 5, 22-37.

Brdar, I., \& Kashdan, T. (2010). Character strengths and well-being in Croatia: An empirical investigation of structure and correlates. Journal of Research in Personality, 44, 151-154.

Broderick , P., \& Metz, S. (2009). Learning to BREATHE: A pilot trial of a mindfulness curriculum for adolescents. Advances in School Mental Health Promotion, 2, 35-46.

Brunwasser, S., \& Gillham, J. (2008). A meta-analytic review of the Penn Resiliency Programme. Paper presented at the Society for Prevention Research, San Francisco, CA, May 2008.

Burchinal, M., Roberts, J., Zeisel, S., \& Rowley, S. (2008). Social risk and protective factors for African American children's academic achievement and adjustment during the transition to middle school. Developmental Psychology, 44, 286-292.

Byrne, D., Davenport, S., \& Mazanov, J. (2007). Profiles of adolescent stress: The development of the Adolescent Stress Questionnaire (ASQ). Journal of Adolescence, 30, 393-416.

Cain, G., \& Carnellor, Y. (2008). 'Roots of empathy': A research study on its impact on teachers in Western Australia. Journal of Student Wellbeing, 2, 52-73.

Campion, J., \& Rocco, S. (2009). Minding the mind: The Effects and potential of a school-based meditation programme for mental health promotion. Advances in School Mental Health Promotion, 2, $47-55$.

Clonan, S., Chafoulea, S., McDougal, J., \& Riley-Tillman, T. (2004). Positive psychology goes to school: Are we there yet? Psychology in the Schools, 41, 101-110. 


\section{Lea Waters}

Cowger, E., \& Torrance, E. (1982). Further examination of the quality of changes in creative functioning resulting from meditation (zazen) training. The Creative Child and Adult Quarterly, 7, 211-217.

Davidson, R., Kabat-Zinn, J., Schumacher, J., Rosenkranz, M., Muller, D., Santorelli, S., Urbanowski, F., Harrington, A., Bonus, K., \& Sheridan, J. (2003). Alterations in brain and immune function produced by mindfulness meditation. Psychosomatic Medicine, 4, 564-570.

Department of Education and Training. (2002). Social competence: A whole school approach to linking learning and wellbeing. Melbourne: Author.

Duck, A., \& Seligman, M. (2005). Self-discipline outdoes IQ in predicting academic performance of adolescents. Psychological Sciences, 16, 939-944.

Durlak, J. A., Weissberg, R. P., Dymnicki, A. B., Taylor, R. D., Schellinger, K. B. (2011). The impact of enhancing students' social and emotional learning: A meta-analysis of school-based universal interventions. Child Development, 82(1), 405-432.

Fielding, M. (2001). Beyond the rhetoric of student voice: New departures or new constraints in the transformation of 21st century schooling? FORUM, 43, 100-112.

Frederickson, B. (2009). Positivity: Groundbreaking research to release your inner optimist and thrive. Oxford, England: Oneworld Publications.

Froh, J., Kashdan, T., Ozimkowski, K., \& Miller, N. (2009). Who benefits the most from a gratitude intervention in children and adolescents? Examining positive affect as a moderator. The Journal of Positive Psychology, 4, 408-422.

Froh, J., Sefick, W., \& Emmons, R. A. (2008). Counting blessings in early adolescents: An experimental study of gratitude and subjective well-being. Journal of School Psychology, 46, 213-233.

Froh, J., Yurkewicz, C., \& Kashdan, T. (2009). Gratitude and subjective well-being in early adolescence: examining mechanisms and gender differences. Journal of Adolescence, 32, 633-650.

Gable, S., \& Haidt, J. (2005). What (and why) is positive psychology? General Psychology, 9, 103-110.

Goleman, D. (1995). Emotional intelligence. New York: Bantam.

Grannis, J. C. (1992). Students' stress, distress, and achievement in an urban intermediate school. The Journal of Early Adolescence, 72(1), 4-27.

Green, S., Anthony, T., \& Rynsaardt, J. (2007). Evidence-based life coaching for senior high school students: Building hardiness and hope. International Coaching Psychology Review, 2, 24-32.

Green, S., Oades, L., \& Robinson, P. (2011). Positive education: Creating flourishing students, staff and schools. InPysch, 16-17, April.

Grossman P, Niemann L, Schmidt, S., \& Walach, H. (2004). Mindfulness-based stress reduction and health benefits: A meta-analysis. Journal of Psychosomatic Research, 57, 35-43.

Huebner, S. (2010). Feelings Count: Conceptualizing and measuring students'happiness in schools. Communiqué: The Newspaper of the National Association of School Psychologists, 39, 1.

Huebner, S., Gilman, R., Reschly, A. J., \& Hall, R. W. (2009). Positive schools. In S. J. Lopez \& C. R. Snyder (Eds.), Oxford handbook of positive psychology (2nd ed.) (pp. 651-658). Oxford, England: Oxford University Press.

Huppert, F., \& Johnson, D. (2010). A controlled trial of mindfulness training in schools: The importance of practice for an impact on well-being. The Journal of Positive Psychology, 5, 264-274

Jackson, A., \& Davis, G. A. (2000). Turning Points 2000: Educating Adolescents in the 21st Century. Williston, VT: Teachers College Press.

Jennings, P., \& Greenberg, M. (2009). The pro-social classroom: Teacher social and emotional competence in relation to student and classroom outcome. Review of Educational Research, 79, 491-525.

Judge, T., \& Kammeyer-Mueller, J. (2011). Happiness as a societal value. Academy of Management Perspectives, February, 30-41.

Kabat-Zinn, J. (1994). Wherever you go, there you are: Mindfulness meditation in everyday life. New York, USA: Hyperion.

Keegan, L. ( 2009). Holistic serenity: Transcending the stresses of leadership. Perioperative Nursing Clinics, 4, 31 .

Keyes , C. (2002). The mental health continuum: From languishing to flourishing. Journal of Health and Social Research, 43(2), 207-222. 
Levine, M. (2009). The positive psychology of buddhism and yoga: Paths to a mature happiness. New York: Routledge.

MacDonald, G., \& Hursh, D. (2006). Twenty-first century schools: Knowledge, networks and economies. Rotterdam, Netherlands: Sense Publishers.

Madden, W., Green, S., \& Grant, T. (2010). A pilot study evaluating strengths-based coaching for primary school students: Enhancing engagement and hope. International Coaching Psychology Review, 6, 71-83.

Marques, S., Lopez, S., \& Pais-Ribeiro, K. (2011). Building hope for the future: A program to foster strengths in middle-school students. Journal of Happiness Studies, 12, 139-152.

Marques, S. C., Pais-Ribeiro, J. L., \& Lopez, S. J. (2009). Validation of a Portuguese version of the Children Hope Scale. School Psychology International, 30, 538-551.

Mayer, J., \& Salovey, P (1997). What is emotional intelligence? In: P. Salovey \& D. Sluyter (Eds.), Emotional development and emotional intelligence: Implications for educators. New York: Basic Books.

McCombs, B., (2004). The learner-centered psychological principles: A framework for balancing academic achievement and social-emotional learning outcomes. In J. Zins, M. Bloodworth, R. Weissberg \& H. Walberg (Eds.), Building academic success in social and emotional learning (pp. 2329). New York: Teachers College Press.

Mission Australia (2007). National survey of young Australians (2007). Melbourne: Author.

Murray-Harvey, R., \& Slee, P. (2007). Supportive and stressful relationships with teachers, peers and family and their influence on students' social/emotional and academic experience of school. Australian Journal of Guidance \& Counselling, 17, 126-147.

National Scientific Council on the Developing Child (2006). Children's emotional development is built into the architecture of their brains. Report 2. Retrieved from www.developingchild.net.

Nidich, S., Mjasiri, S., Nidich, R., Rainforth, M., Grant, J., Valosek, L., Change, W., \& Zigler, R. (2011). Academic achievement and transcendental meditation: A study with at-risk urban middle school students. Education, 131, 556-564.

Noble, T., \& McGrath, H. (2008). The positive educational practices framework: A tool for facilitating the work of educational psychologists in promoting pupil wellbeing. Educational \& Child Psychology, $25,119-134$.

Noddings, N. (1995). A morally defensible mission for schools in the twenty first century. The Phi Delta Kappan, 76, 365-368.

Norrish, J., \& Vella-Brodrick, D. (2009). Positive psychology and adolescents: Where are we now? Where to from here? Australian Psychologist, 44, 270-278.

Palmer, P. (2003). Teaching with heart and soul: Reflections on spirituality in teacher education. Journal of Teacher Education, 54, 376-385.

Park, N., \& Peterson, C. (2008). Positive psychology and character strengths: Application to strengthsbased school counseling. Professional School Counseling, 12, 85-92.

Park., N., \& Peterson, C. (2009a). Character strengths: Research and practice. Journal of College \& Character, $X(4), 2-10$.

Park, N., \& Peterson, C. (2009b). Strengths of character in school. In R. Gilman, E. S. Huebner., \& M. J. Furlong. (Eds.), Handbook of positive psychology in schools (pp. 77-88). New York: Routledge.

Park, N., Peterson, C., \& Seligman, M. (2004). Strengths of character and well-being. Journal of Social and Clinical Psychology, 23, 603-619.

Pawelski, J. (in press). Conceptual questions in positive psychology. French Anthology.

Peterson, C. (2006). A primer in positive psychology. New York: Oxford University Press.

Peterson, C., Ruch, W., Beermann, U., Park, N., \& Seligman, M. E. P. (2007). Strengths of character, orientations to happiness, and life satisfaction. Journal of Positive Psychology, 2, 149-156.

Peterson, C., \& Seligman, M., (2004). The VIA classification of strengths. Cincinnati: Values in Action Institute.

Reivich, K., \& Shatte, A. (2002). The resilience factor: 7 keys to finding your inner strengths and overcoming life' hurdles. Skills for overcoming life's inevitable obstacles. New York: Broadway Books.

Seligman, M. (2011). Flourish: A Visionary new understanding of happiness and well-being. New York: Free Press. 


\section{Lea Waters}

Seligman, M., \& Csikszentmihalyi, M., (2000). Positive psychology: An Introduction. American Psychologist, 55, 5-14.

Seligman, M., Ernst, R., Gillham, J., Reivich, K., \& Linkin, M. (2009). Positive education: Positive psychology and classroom interventions. Oxford Review of Education, 35, 293-311.

Sin, N., \& Lyubomirsky, S. (2009). Enhancing well-being and alleviating depressive symptoms with positive psychology interventions: A practice-friendly meta-analysis. Journal of Clinical Psychology: In Session, 65, 467-487.

Snyder, C.R. (1995). Conceptualising, measuring and nurturing hope. Journal of Counselling and Development, 73, 355-360.

Thygeson, M., Hooke, M., Clapsaddle, J., Robbins, A., \& Moquist, K. (2010). Peaceful play yoga: Serenity and balance for children with cancer and their parents. Journal of the Association of Pediatric Oncology Nurses, 27, 276.

Tucci, J., Mitchell, J., \& Goddard, C. (2007). Children's fears, hopes and heroes: Modern childhood in Australia. Melbourne: Australian Childhood Foundation and National Research Centre for the Prevention of Child Abuse.

Valle, M. F., Huebner, E. S., \& Suldo, S. M. (2006). An analysis of hope as a psychological strength. Journal of School Psychology, 44, 393-406.

Wickramaratne, P. J., Weissman, M. M., Leaf, P. J., \& Holford, T. R. (1989). Age, period and cohort effects on the risk of major depression: Results from five United States communities. Journal of Clinical Epidemiology, 42, 333-343.

Wong, P. (2011). Positive psychology 2.0: Towards a balanced interactive model of the good life. Canadian Psychology, 52, 69-81.

Yates, L. (2007). Learning to 'become somebody well': Challenges for educational policy. The Australian Educational Researcher, 34, 35-52.

Yost, M. (1967). A longitudinal study of reactive curiosity, manifest anxiety and achievement in elementary school. Minesota: Upper Midwest Regional Educational Laboratory. 